\title{
EFFECT OF TADALAFIL ADD-ON THERAPY IN PATIENTS WITH LOWER URINARY TRACT SYMPTOMS DUE TO BENIGN PROSTATIC HYPERPLASIA REFRACTORY TO TAMSULOSIN MONOTHERAPY: RANDOMIZED, CONTROLLED TRIAL
}

By

\author{
Omar M. Nasef*, Abd El-Rhman E. Ebid and Ayman K. Koritenah \\ Department of Urology, Faculty of Medicine, Al-Azhar University \\ *Corresponding author: Omar M. Nasef,
}

Mobile: 01060826422, E-mail: o.nassef92@ gmail.com

\begin{abstract}
Background: Benign prostatic hyperplasia (BPH) is a non-malignant hyperplasia of prostatic cells.Most of patients with BPH present with lower urinary tract symptoms (LUTS). LUTS and BPH are highly prevalent entities in aging men.

Objectives: To assess the efficacy and safety of fixed-dose combination therapy of Tamsulosin $0.4 \mathrm{mg}$ plus Tadalafil $5 \mathrm{mg}$ versus Tamsulosin $0.4 \mathrm{mg}$, plus placebo once daily in the treatment of patients with LUTS related to BPH whose were refractory to tamsulosin monotherapy.

Patients and Methods: In this randomized controlled clinical study, carried out at Al-Azhar University Hospitals, 80 patients complaining of LUTS related to BPH were randomly divided into two equal groups. Fortypatients received fixed-dose combinations therapy of Tamsulosin $0.4 \mathrm{mg} /$ day and tadalafil $5 \mathrm{mg} /$ day for 6 months (group A), and forty patients received Tamsulosin $0.4 \mathrm{mg}$ plus placebo/day for 6 months (group B). The International Prostate Symptom Score (IPSS), Qmax, Post void residual urine (PVRU) and International Index of Erectile Function (IIEF-5) score used at baseline before starting treatment, at 3 months and 6 months to assess the efficacy in both groups.

Results: With combination therapy group, there was significant improvement in IPSS score P value $(<0.001)$, significant increase in Qmax P value $(<0.001)$, and significant decrease in PVRU P value $(<0.001)$ compared with placepo group. IIEF- 5 score changes showed no statistically significant difference between bothgroups ( $\mathrm{P}$ value) (0.102) in tadalafil group.

Conclusion: The fixed-dose combination of Tamsulosin $0.4 \mathrm{mg} /$ day and Tadalafil $5 \mathrm{mg} /$ day are significantly superior to Tamsulosin $0.4 \mathrm{mg} / \mathrm{day}$ plus placebo for the treatment of LUTS related to BPH whose were refractory to tamsulosin, supporting favorable benefit-risk balance of the fixed-dose combinations therapy for the treatment of LUTS related to BPH because of its synergistic effects, well toleration and safety.
\end{abstract}

Key words: Tadalafil, LUTS, BPH, Tamsulosin.

\section{INTRODUCTION}

Benign prostatic hyperplasia $(\mathrm{BPH})$ is a disorder histologically characterized as the non-malignant hyperplasia of prostatic cells. Most of patients with BPH present with lower urinary tract symptoms (LUTS). About half of men develop BPH, among these; about half develop some 
degree of bladder outlet obstruction (BOO). BOO and/or changes in smooth muscle tone and resistance that can accompany BPH may result in (LUTS) (Gravas et al., 2015).

LUTS include storage disturbances (such as daytime urinary urgency and nocturia) and/or voiding disturbances (such as urinary hesitancy, weak urinary stream, straining to void, and prolonged voiding). LUTS affect an estimated 3 percent of men ages 45-49 years old increasing to around 30 percent of men over 85 years old. Urinary hesitancy, weak stream, and nocturia are the most commonly reported LUTS (Karami et al., 2016).

Treatment decisions can typically be based on symptoms and degree of bother without need to perform specialized tests such as uroflowmetry and PVRU measurement. Lifestyle interventions such as modifying fluid intake or toileting behavior are typically the first-line treatments to reduce symptoms in patients with LUTS/BPH. When necessary, pharmacological treatment also may be initiated to reduce symptoms and prevent or delay disease progression (Strittmatter et al., 2013).

Alpha-blockers have been widely used for the treatment of LUTS/BPH for a long time. Some alpha-blockers may cause ejaculatory dysfunction in some individuals.

Tadalafil, a (PDE-5), was approved by the Food and Drug Administration (FDA) for the treatment of (ED) in 2003 and for the treatment of BPH in 2011 (Singh et al., 2014).
The PDE5 inhibitors are used in the treatment of ED and there are increasing data of effects of these drugs on bladder and urethral relaxation as well as of prostatic smooth muscles that may relief the symptoms of BPH (Wang et al., 2015).

The inclusion of Tadalafil in complex of combined conservative therapy of patients with BPH not only improves sexual function but has a positive effect on symptoms of the disease and the psychological state of the patient (Reges et al., 2012).

The aim of this study was to evaluate the efficacy and safety of once daily PDE5-I (tadalafil) as an add-on treatment for men with (BPH/LUTS) refractory to tamsulosin monotherapy.

\section{PATIENTS AND METHODS}

This was a prospective study conducted on a total of 80 patients who were complaining of LUTS associated with BPH. They were recruited from Urology Outpatient Clinics at AL-Hussein and Sayed Galal University hospitals from November 2019 to September 2020.

All patients fully under stood the treatment and aim of this study. Written informed consent was obtained from patients as well as the ethicscommittee of University.

The study included BPH patients with persistent LUTS, IPSS $\geq 8$ and receiving alpha 1 blocker (tamsulosin) for at least 3 months.

\section{Exlcusion criteria:}

- Age $<50$ years.

- Prostate size $<20 \mathrm{cc}$. 
- Total serum prostatic specific antigen $(\mathrm{PSA})>4 \mathrm{ng} / \mathrm{ml}$.

- History or evidence of prostatic cancer.

- Previous prostatic surgery or other invasive procedure to treat $\mathrm{BPH}$.

- Post voiding residual (PVR) of urine volume > $100 \mathrm{ml}$ (suprapubic ultrasound).

- History of acute urinary retention (AUR) within 3 months prior to study.

- Any case of LUTS other than BPH (urinary bladder stone, neurogenic bladder, bladder neck contracture, urethral stricture, bladder cancer, acute or chronic prostatitis, acute or chronic urinary tract infection).

- Use of any PDE51 within the past 2 weeks prior to the study.

- Contraindication to PDE51 (e.g., patients taking nitrate or nitroglycerin and recent myocardial infarction).

All patients underwent pre-treatment, 3 and 6 months post-treatment assessment of the following parameters:

- Detailed medical and surgical history.

- Physical examination.

- Urine analysis.

- Blood analysis including prostatespecific antigen (PSA), renal function tests (blood urea and serum creatinine).

- Pelvic-abdominal Ultrasound-to assess prostatic size, and determination of post-voiding residual urine (PVR), concomitant urinary bladder pathology and upper urinary tract.

- Uroflowmetry (UFM): to determine peak flow rate, or Qmax. Peak flow rate along voiding pattern and urine volumes, to determine the severity of any blockage or obstruction.

- International index of erectile function (IIEF-5): This is a multidimensional scale that can be used to evaluate ED.

Eligible patients were randomized to receive fixed dose of Tamsulosin 0.4 $\mathrm{mg}$ /day plus Tadalafil $5 \mathrm{mg} /$ day (Group A) or Tamsulosin $0.4 \mathrm{mg} /$ day plus daily placebo (Group B) for 6months.

Patients were followed after 3, 6 months by Medical history to evaluate symptoms and possible side effects such as (backache, blurred of vision and hypotension), physical examination, Complete urine analysis, uroflowmetry Changes, Ultrasound with measurement ofPVRU, IPSS, QoL score and IIEF-5 score.

Outcomes measured were the mean changes of IPSS, QOL score, Qmax and PVRU, all of these parameters were also compared with the baseline parameters.

Patients were instructed during the study to avoid hold of micturition, exposure to cold, prolonged setting and drugs that can affect bladder contraction or storage such as antihistamines and antimuscarinic.

The primary end point is the change in the mean IPSS scores to detect difference in total IPSS from baseline (weak 0) to (weak 24) between tadalafil5 $\mathrm{mg}$ and placebo group. The secondary end points are change in the mean values of the following parameters: Qmax and PVRU.

\section{Statistical analysis:}

Recorded data were analyzed using the statistical package for the social sciences, version 20.0 (SPSS Inc., Chicago, Illinois, 
USA). Quantitative data were expressed as mean \pm standard deviation (SD). Qualitative data were expressed as frequency and percentage. The following tests were done: Independent-samples ttest of significance was used when comparing between two means. Repeated measures ANOVA tests for whether there are any differences between related means. Post Hoc test: Least Significant Difference (LSD) was used for multiple comparisons between different variables for parametric data; also Mann-Whitney U test was used to compare between the two groups, and comparison between two related samples for non-parametric data using Wilcoxon Rank Sum test for nonparametric data. Chi-square (x2) test of significance was used in order to compare proportions between qualitative parameters. The confidence interval was set to $95 \%$ and the margin of error accepted was set to $5 \%$. So, the P-value $<0.05$ was considered significant.

\section{RESULTS}

\section{Baseline characteristics:}

No statistically significant difference was found between groups according to baseline characteristics. The Ages in Tadalafil group ranged between 51-76 years old with Mean \pm SD was $60.51 \pm$
6.93 while in placebo it ranged between 51-76 years old with Mean \pm SD $62.05 \pm$ 6.87. $43.9 \%$ were diabetic in Tadalafil group versus $24.4 \%$ in placebo group (Table 1).

Table (1): Comparison between PDE5 I 5mg group and Placebo group according to baseline characteristics

\begin{tabular}{|c|c|c|c|c|}
\hline $\begin{array}{l}\text { Baseline } \\
\text { characteristics }\end{array}$ & $\begin{array}{c}\text { PDE5 I 5mg } \\
\text { Group }(n=41)\end{array}$ & $\begin{array}{l}\text { Placebo Group } \\
\qquad(n=41)\end{array}$ & $t / x 2 \#$ & p-value \\
\hline \multicolumn{5}{|l|}{ Age (years) } \\
\hline Mean \pm SD & $60.51 \pm 6.93$ & $62.05 \pm 6.87$ & \multirow{2}{*}{1.017} & \multirow{2}{*}{0.316} \\
\hline Range & $51-76$ & $51-76$ & & \\
\hline DM & $18(43.9 \%)$ & $10(24.4 \%)$ & $2.653 \#$ & 0.103 \\
\hline HTN & $5(12.2 \%)$ & $10(24.4 \%)$ & 1.306\# & 0.253 \\
\hline \multicolumn{5}{|l|}{ Total PSA } \\
\hline Mean \pm SD & $2.94 \pm 0.63$ & $2.92 \pm 0.62$ & \multirow{2}{*}{0.020} & \multirow{2}{*}{0.888} \\
\hline Range & $1.8-3.9$ & 1.9-3.9 & & \\
\hline History of PDE5i & $4(9.8 \%)$ & $7(17.1 \%)$ & $0.416 \#$ & 0.519 \\
\hline \multicolumn{5}{|l|}{ Prostate size } \\
\hline Mean \pm SD & $43.76 \pm 6.69$ & $47.71 \pm 7.71$ & \multirow{2}{*}{1.143} & \multirow{2}{*}{0.153} \\
\hline Range & $32-66$ & $33-62$ & & \\
\hline
\end{tabular}

There was a statistically significant decrease in the mean PVRU/ml in tadalafil 5mg group compared to placebo after 3 and 6 months (Table 2). 
Table (2): Comparison between both groups according to PVRU

\begin{tabular}{|c|c|c|c|c|}
\hline PVRU Iml Groups & $\begin{array}{l}\text { Tadalafil } 5 \mathrm{mg} \\
\text { group }(n=41)\end{array}$ & $\begin{array}{l}\text { Placebo group } \\
\qquad(n=41)\end{array}$ & $\begin{array}{c}\text { Mann- } \\
\text { Whitney U- } \\
\text { test }\end{array}$ & p-value \\
\hline \multicolumn{5}{|l|}{ Before study } \\
\hline Mean \pm SD & $46.61 \pm 24.20$ & $52.85 \pm 24.47$ & \multirow{2}{*}{1.241} & \multirow{2}{*}{$>0.05$} \\
\hline Range & $0-86$ & $0-92$ & & \\
\hline \multicolumn{5}{|l|}{ After 3 months } \\
\hline Mean \pm SD & $28.02 \pm 20.72$ & $47.85 \pm 25.42$ & \multirow{2}{*}{4.491} & \multirow{2}{*}{$<0.001$} \\
\hline Range & $0-76$ & $0-100$ & & \\
\hline \multicolumn{5}{|l|}{ After 6 months } \\
\hline Mean \pm SD & $17.29 \pm 23.01$ & $50.41 \pm 25.04$ & \multirow{2}{*}{7.560} & \multirow{2}{*}{$<0.001$} \\
\hline Range & $0-90$ & $0-110$ & & \\
\hline
\end{tabular}

There was a statistically significant

$5 \mathrm{mg}$ group compared to placebo after increase in the mean Qmax in tadalafil 3and 6 months (Table 3).

Table (3): Comparison between both groups according to Q- max

\begin{tabular}{|c|c|c|c|}
\hline$Q_{\max }$ Groups & $\begin{array}{l}\text { Tadalafil 5mg } \\
\text { group }(n=41)\end{array}$ & $\begin{array}{l}\text { Placebo group } \\
\quad(n=41)\end{array}$ & p-value \\
\hline \multicolumn{4}{|l|}{ Before study } \\
\hline Mean \pm SD & $11.66 \pm 1.93$ & $12.29 \pm 1.94$ & \multirow{2}{*}{$>0.05$} \\
\hline Range & $7-15$ & $7-15$ & \\
\hline \multicolumn{4}{|l|}{ After 3 months } \\
\hline Mean \pm SD & $14.68 \pm 2.09$ & $12.27 \pm 2.16$ & \multirow{2}{*}{$<0.001$} \\
\hline Range & 8-18 & $8-16$ & \\
\hline \multicolumn{4}{|l|}{ After 6 months } \\
\hline Mean \pm SD & $15.51 \pm 2.67$ & $12.27 \pm 2.18$ & \multirow{2}{*}{$<0.001$} \\
\hline Range & $7-19$ & $8-16$ & \\
\hline
\end{tabular}

t-Independent Sample t-test;

No statistically significant difference was found between groups according to IIEF\% at pre and after 6months (Table 4).

Table (4): Comparison between both groups according to IIEF5

\begin{tabular}{|c|c|c|c|}
\hline IIEF5 & $\begin{array}{l}\text { Tadalafil 5mg } \\
\text { group }(n=41)\end{array}$ & $\begin{array}{c}\text { Placebo group } \\
(n=41)\end{array}$ & p-value \\
\hline \multicolumn{4}{|l|}{ Before study } \\
\hline Mild & $8(19.5 \%)$ & $11(26.8 \%)$ & \multirow{5}{*}{$>0.05$} \\
\hline Moderate & $14(34.1 \%)$ & $16(39.0 \%)$ & \\
\hline Sever & $9(22.0 \%)$ & $8(19.5 \%)$ & \\
\hline No ED & $6(14.6 \%)$ & $3(7.3 \%)$ & \\
\hline Not interested & $4(9.8 \%)$ & $3(7.3 \%)$ & \\
\hline \multicolumn{4}{|l|}{ After 6 months } \\
\hline Mild & $13(31.7 \%)$ & $9(22.0 \%)$ & \multirow{5}{*}{$>0.05$} \\
\hline Moderate & $6(14.6 \%)$ & $16(39.0 \%)$ & \\
\hline Sever & $7(17.1 \%)$ & $8(19.5 \%)$ & \\
\hline No ED & $11(26.8 \%)$ & $5(12.2 \%)$ & \\
\hline Not interested & $4(9.8 \%)$ & $3(7.3 \%)$ & \\
\hline
\end{tabular}


Only fifteen patients of all studied cases complained of the following adverse effects (backache, headache, blurring of vision and hypotension). All of them were received tadalafil. No statistically significant difference was found between groups according to side effect of medical treatment at after 3 months and after 6 months (Table 5).

Table (5): Comparison between both groups according to side effect of medical treatment

\begin{tabular}{|l|c|c|c|}
\hline $\begin{array}{l}\text { Side effects of } \\
\text { medical treatment }\end{array}$ & $\begin{array}{c}\text { Tadalafil 5mg } \\
\text { group }(\mathbf{n = 4 1 )}\end{array}$ & $\begin{array}{c}\text { Placebo group } \\
(\boldsymbol{n}=\mathbf{4 1})\end{array}$ & p-value \\
\hline After 3 months & \multicolumn{3}{|l|}{} \\
\hline Backache & $2(4.9 \%)$ & $0(0.0 \%)$ & $>0.05$ \\
\hline Blurred Vision & $3(7.3 \%)$ & $0(0.0 \%)$ & $>0.05$ \\
\hline Headache & $4(9.8 \%)$ & $0(0.0 \%)$ & $>0.05$ \\
\hline Hypotention & $2(4.9 \%)$ & $0(0.0 \%)$ & $>0.05$ \\
\hline After 6 months & $0(0.0 \%)$ & $>0.05$ \\
\hline Bachache & $1(2.4 \%)$ & $0(0.0 \%)$ & $>0.05$ \\
\hline Blurred Vision & $1(2.4 \%)$ & $0(0.0 \%)$ & $>0.05$ \\
\hline
\end{tabular}

There was a statistically significant difference was found between category measurement according to PVRU, Qmax,
QoL and IPSS in the pretreatment, after 3 months and after 6 months (Table 6).

Table (6): Comparison between pre, after 3 months and after 6months according to PVRU Iml, Q max, QoL, IIEF5 and IPSS in Tadalafil 5mg group

\begin{tabular}{|c|c|c|c|c|c|c|}
\hline $\begin{array}{l}\text { Tadalafil } \\
\text { 5mg group }\end{array}$ & Pre $(n=41)$ & $\begin{array}{c}\text { After 3 } \\
\text { months } \\
(\mathrm{n}=41) \\
\end{array}$ & $\begin{array}{c}\text { After } 6 \\
\text { months } \\
(\mathrm{n}=41) \\
\end{array}$ & P1 & $\mathbf{P 2}$ & P3 \\
\hline PVRU $\backslash \mathrm{ml} \mathbf{l}^{¥}$ & $46.61 \pm 24.20$ & $28.02 \pm 20.72$ & $17.29 \pm 23.01$ & $<0.001 * *$ & $<0.001 * *$ & $<0.001$ \\
\hline Q max & $11.66 \pm 1.93$ & $14.68 \pm 2.09$ & $15.51 \pm 2.67$ & $<0.001 * *$ & $<0.001 * *$ & $<0.001$ \\
\hline $\mathbf{Q o L}^{\mp}$ & $3.37 \pm 0.62$ & $2.71 \pm 0.93$ & $2.17 \pm 1.09$ & $<0.001 * *$ & $<0.001 * *$ & $<0.001$ \\
\hline \multicolumn{7}{|l|}{ IIEF5\# } \\
\hline Mild & $8(19.5 \%)$ & -- & $13(31.7 \%)$ & -- & 0.311 & -- \\
\hline Moderate & $14(34.1 \%)$ & -- & $6(14.6 \%)$ & -- & 3.239 & -- \\
\hline No ED & $6(14.6 \%)$ & -- & $11(26.8 \%)$ & -- & 0.275 & -- \\
\hline Not interested & $4(9.8 \%)$ & -- & $4(9.8 \%)$ & -- & 1.000 & -- \\
\hline Sever & $9(22.0 \%)$ & -- & $7(17.1 \%)$ & -- & 0.778 & -- \\
\hline IPSS $^{¥}$ & $12.15 \pm 3.93$ & $5.88 \pm 4.13$ & $4.12 \pm 4.76$ & $<0.001 * *$ & $<0.001 * *$ & 0.029 \\
\hline
\end{tabular}

Using: $\$$ Repeated Measurement ANOVA; $¥ W$ ilcoxon Test; \#Chi-square test

P1: Comparison between pre and after 3 months; P2: Comparison between pre and after 6 months; P3: Comparison between after 3 months and after 6 months

No statistically significant difference was found between category measurement according to PVRU, Qmax, QoL, IIEF5 and IPSS in pretreatment, after 3 months \& after 6 months (Table 7). 
Table (7): Comparison between pre, after 3 months and after 6 months according to PVRU Iml, Q max, QoL, IIEF5 and IPSS in Placebo group

\begin{tabular}{|c|c|c|c|c|c|c|}
\hline $\begin{array}{ll}\text { Placebo } & \text { Duration } \\
\text { Group } & \end{array}$ & $\begin{array}{c}\text { Pre } \\
(n=41)\end{array}$ & $\begin{array}{c}\text { After } 3 \\
\text { months } \\
(n=41)\end{array}$ & $\begin{array}{c}\text { After } 6 \\
\text { months } \\
(n=41)\end{array}$ & P1 & $\mathbf{P 2}$ & P3 \\
\hline PVRU $\backslash \mathrm{ml}^{¥}$ & $52.85 \pm 24.47$ & $47.85 \pm 25.42$ & $50.41 \pm 25.04$ & 0.143 & 0.620 & 0.315 \\
\hline Q maxt & $12.29 \pm 1.94$ & $12.27 \pm 2.16$ & $12.27 \pm 2.18$ & 0.912 & 0.921 & 1.000 \\
\hline QoL $^{¥}$ & $3.44 \pm 0.63$ & $3.37 \pm 0.80$ & $3.49 \pm 0.87$ & 0.467 & 0.756 & 0.150 \\
\hline \multicolumn{7}{|l|}{ IIEF5\# } \\
\hline Mild & $11(26.8 \%)$ & -- & $9(22.0 \%)$ & -- & 0.803 & -- \\
\hline Moderate & $16(39.0 \%)$ & -- & $16(39.0 \%)$ & -- & 1.000 & -- \\
\hline No ED & $3(7.3 \%)$ & -- & $5(12.2 \%)$ & -- & 0.707 & -- \\
\hline Not interested & $3(7.3 \%)$ & -- & $3(7.3 \%)$ & - & 1.000 & - \\
\hline Sever & $8(19.5 \%)$ & -- & $8(19.5 \%)$ & -- & 1.000 & -- \\
\hline IPSS $^{\mp}$ & $12.46 \pm 3.71$ & $12.20 \pm 3.84$ & $12.46 \pm 4.08$ & 0.348 & 1.000 & 0.260 \\
\hline
\end{tabular}

Using: $¥$ Repeated Measurement ANOVA; $¥ W$ ilcoxon Test; \#Chi-square test

\section{DISCUSSION}

Improvement in BPH/LUTS was evident from in 4 pivotal randomized, double blind, placebo controlled studies that reported a significantly greater mean change in total IPSS from baseline to week 12 (Egerdie et al., 2012 and Oelke et al., 2012).

However, efficacy of PDE5Itadalafil as an add-on treatment for men with BPH/LUTS refractory to an alpha 1ablocker has been not reported to date.

Several studies have studied the efficacy of monotherapy with tadalafil and tamsulosin. Also, there are studies on their combination with other drugs or comparing them with each other.

Yagi et al. (2017) in his prospective randomized study showed a significant improvement in LUTS, as indicated by change in the mean IPSS scores in terms of total score, storage sub score, voiding sub score and QOL .The mean Qmax and PVR did not significantly change. The frequency volume chart (FVC) showed significant improvements in hours of undisturbed sleep (HUS), nocturnal polyuria index, and mean number of micturations per night not in the mean number of micturitions per day. There were no significant improvements in sexual function. They study used tamsulosin 0.2 and follow up was shorter, while we used tamsulosin $0.4 \mathrm{mg}$ as fixed dose and follow up was longer.

Our study showed similar results that the improvement in IPSS scores is better with combination therapy compared with Tamsulosin alone in patient that are resistant to a1-blocker.

Kim et al. (2017) in a randomized, double-blinded, active-controlled trial among 510 men with BPH-associated LUTS and ED were included and randomly treated with fixed-dose combinations of Tamsulosin $0.4 \mathrm{mg}$ plus Tadalafil $5 \mathrm{mg}$, tamsulosin $0.2 \mathrm{mg}$ plus tadalafil $5 \mathrm{mg}$ and tadalafil $5 \mathrm{mg}$ for a 12week period. We found that the mean changes in total IPSS and IIEF-5 scores were 9.46 and 9.17 for fixed-dose combinations $0.4 / 5 \mathrm{mg}$ and 8.14 and 9.49 for Tadalafil $5 \mathrm{mg}$, respectively, which 
indicated superiority in LUTS improvement and non-inferiority in ED treatment with fixed-dose combinations $0.4 / 5 \mathrm{mg}$ compared with tadalafil $5 \mathrm{mg}$. Our study results were similar to Kim et al. (2017). The fixed-dose combinations of Tamsulosin $0.4 \mathrm{mg} /$ day and Tadalafil 5 $\mathrm{mg} /$ day were significantly superior to Tadalafil $5 \mathrm{mg} /$ day alone and tamsulosin $0.2 \mathrm{mg}$ plus tadalafil $5 \mathrm{mg}$ for the treatment of BPH patients with LUTS. They clearly demonstrated the advantage of fixed dose combination (FDC) $0.4 / 5$ $\mathrm{mg}$. The main advantage of FDC $0.4 / 5 \mathrm{mg}$ was the enhanced efficacy on BPHassociated LUTS; however, the lack of a tamsulosin monotherapy control group was a limitation of this study.

Urakamet al. (2018), in his pilot study, examined the efficacy and safety of tadalafil add-on therapy for BPH/OAB that persists after treatment with an alphablocker by comparing tadalafil $(5 \mathrm{mg}$ ) with solifenacin $(5 \mathrm{mg})$. The study showed that the median prostate volume was 43 and $40 \mathrm{~mL}$, respectively, with no significant differences between the two groups as baseline characteristics.

Significantly improved the IPSS (total), IPSS (storage symptoms), QOL index, and nocturia frequency (IPSS-Q7) improved significantly after 4 and 12 weeks of treatment compared with before treatment in both groups. However, although the IPSS (voiding symptoms) improved significantly after 4 and 12 weeks treatment compared with before treatment in the tadalafil group. Qmax did not improve significantly after 4- and 12weeks treatment compared with before treatment in either group. A significant improvement in Qave was only seen after
4 weeks treatment (vs before treatment) in the tadalafil group. These results demonstrated the efficacy of tadalafil addon therapy in the treatment of persistent storage symptoms after alpha-blocker treatment for BPH/LUTS. In addition, nocturia, which markedly decreased the QOL of patients, improved significantly after 4 and 12 weeks tadalafil treatment.

Urakam et al. (2018), showed similar results as improvement in IPSS, Qol and Qave, but no improvement in Qmax. A short duration may be the reason why there were no significant differences in comparisons of some of the parameters evaluated.

Singh et al. (2014) is a prospective randomized study showed better improvement with combination therapy compared with Tadalafil alone. In our study, we obtained similar result.

\section{Strength points:}

1. Long time of follow up.

2. Randomized controlled single blind clinical study.

\section{Weak points:}

1. The number of patients was small to get a solid conclusion.

2. A patient in combination regimen (tadalafil plus tamsulosin) has the tendency to have greater psychogenic effect of improvement compared with placebo group that may lead to greater perceived benefit in subjective parameters.

\section{CONCLUSION}

The fixed-dose combination of Tamsulosin $0.4 \mathrm{mg} /$ day and Tadalafil $5 \mathrm{mg}$ /day were significantly superior to 
Tamsulosin $0.4 \mathrm{mg} /$ day plus placebo for the treatment of BPH patients with LUTS that were refractory to tamsulosin, supporting favorable benefit-risk balance of the fixed-dose combinations of therapy for the treatment of BPH patients with LUTS because of its synergistic effects, well toleration and its safety.

\section{Conflict of interest: None.}

\section{REFERENCES}

1. Egerdie RB, Auerbach S, Roehrborn CG, Costa P, Garza MS, Esler AL and Secrest RJ. (2012): Tadalafil 2.5 or $5 \mathrm{mg}$ administered once daily for 12 weeks in men with both erectile dysfunction and signs and symptoms of benign prostatic hyperplasia: Results of a randomized, placebo-controlled, double-blind study. The Journal of Sexual Medicine, 9(1): 271-281.

2. Gravas S, Cornu JN, Gacci M, Gratzke C, Herrmann TR, Mamoulakis C, Rieken M, Speakman MJ and Tikkinen KA. (2015): Guidelines on the management of nonneurogenicmalelowerurinarytract symptoms (LUTS), incl. benignpro static obstruction (BPO). EAU Guidelines, 215(33): 79-84.

3. Karami H, Hassan zadeh- Hadad A and Fallah-Karkan M. (2016): Comparing monotherapy with tadalafil or tamsulosin and their combination therapy inmen with benignprostatic hyperplasia: a randomized clinical trial. UrolJ., 13: 2920-2926.

4. Kim SW, Park NC, Lee SW, Yang DY, Park JK, Moon DG, Yang SK, Lee SW, Moon KH, Ahn TY and Kim SW. (2017): Efficacy and safety of a fixed-dose combination therapy of tamsulosin and tadalafil for patients with lower urinary tract symptoms and erectile dysfunction: results of a randomized, doubleblinded, active-controlled/trial. The Journal of Sexual Medicine; 14(8):1018-27.

5. Oelke M, Giuliano F, Mirone V, Xu L, Cox $D$ and Viktrup L. (2012): Monotherapy with tadalafil or tamsulosin similarly improved lower urinary tract symptoms suggestive of benign prostatic hyperplasia in an international, randomized, parallel, placebo-controlled clinical trial. European Urology: 61(5), 917925.

6. Reges R, Regadas R, Moraes Filho MO, Jamacaru FV, Cerqueira JB and Gonzaga LF. (2012): The association of tamsulosin and daily tadalafil for the treatment of lower urinary tract symptoms is safe and effective? $\mathbf{J}$ Urol., 187: e507-511.

7. Singh DV, Mete UK, Mandal AK and Singh SK. (2014): A comparative randomized prospective study to evaluate efficacy and safety of combination of tamsulosin and tadalafil vs. tamsulosin or tadalafil alone in patients with lower urinary tract symptoms due to benign prostatic hyperplasia. J Sex Med., 11: 187-196.

8. Strittmatter F, Gratzke C, Stief CG and Hedlund P. (2013): Current pharmacological treatment options for male lower urinary tract symptoms. Expert Opinion on Pharmacotherapy; 14(8):1043-54.

9. Urakami S, Ogawa K, Oka S, Hagiwara K, Nagamoto $S$, Anjiki $H$ and Okaneya $T$. (2019): Effect of tadalafil add-on therapy in patients with persistent storage symptoms refractory to $\alpha 1$-adrenoceptor antagonist monotherapy for benign prostatic hyperplasia: A randomized pilot trial comparing tadalafil and solifenacin. LUTS: Lower Urinary Tract Symptoms, 11(3): 109114.

10. Wang XH, Wang X, Shi MJ, Li S and Liu T, Zhang XH. (2015): Systematic review and meta-analysis on phosphodiesterase 5 inhibitors and $\alpha$-adrenoceptor antagonists used alone or combined for treatment of LUTS due to BPH. Asian Journal of Andrology, 7(6):1022-1029.

11. Yagi H, Arai G, Soh S and Okada H. (2017): Efficacy of Tadalafil Add-on Treatment for Men with Lower Urinary Tract Symptoms Refractory to Alpha-1 Adrenoceptor Blockers. Dokkyo Journal of Medical Sciences, 44(1): 17-23. 


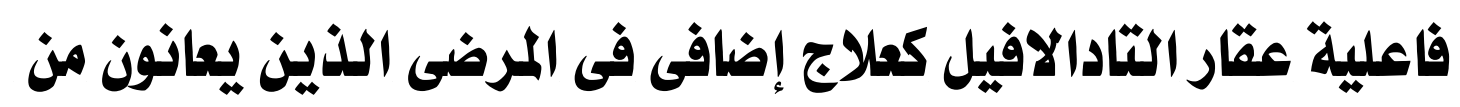

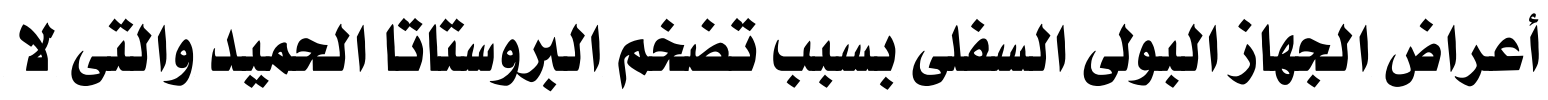

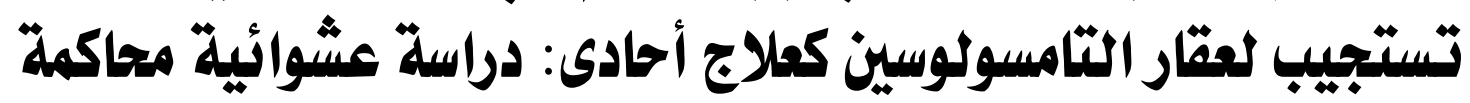
عمر محمد عبد الوهاب ناصف، عبد الرحمن إبراهيم عبد الرحمن عبيد، أيمن قطب

\section{محمد قريطنه}

قسم جراحة المسالك البولية، كلية الطب، جامعة الأزهر

E-mail: o.nassef92@gmail.com

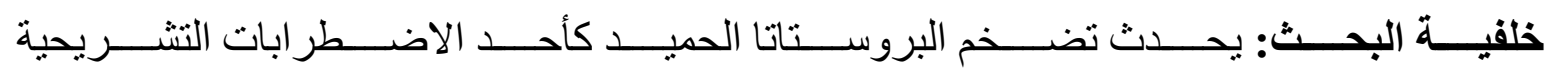

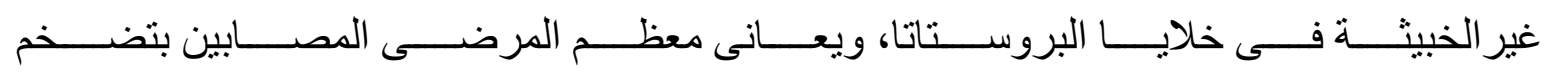

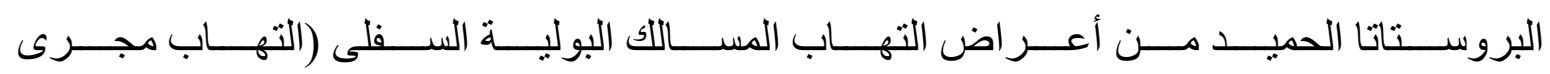

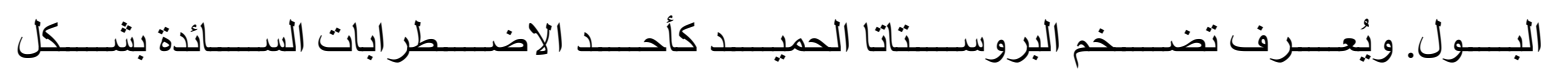

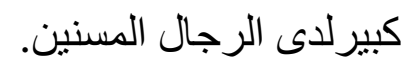

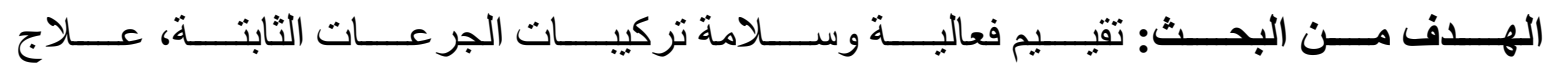

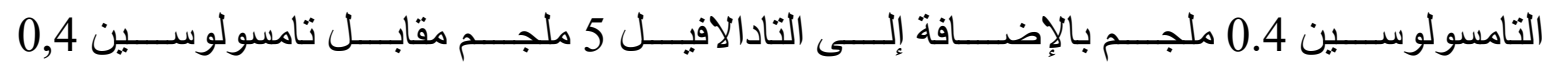

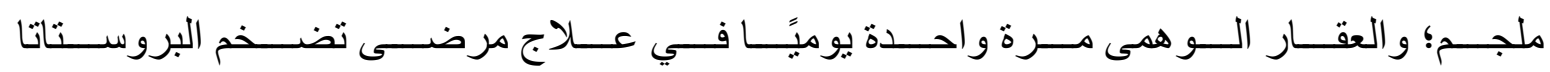

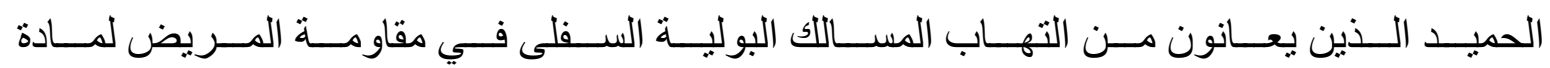
تامسولوسين.

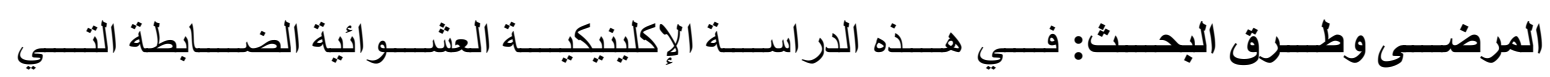

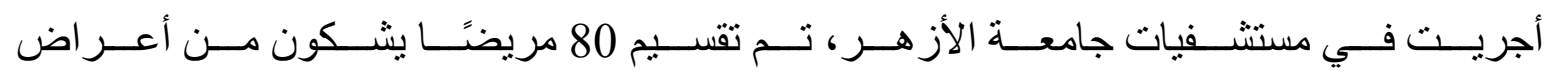

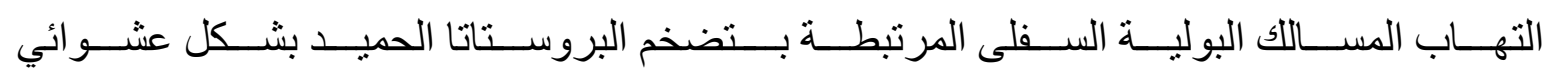

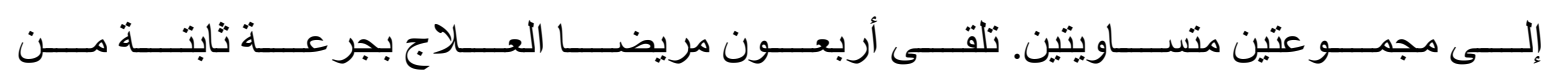

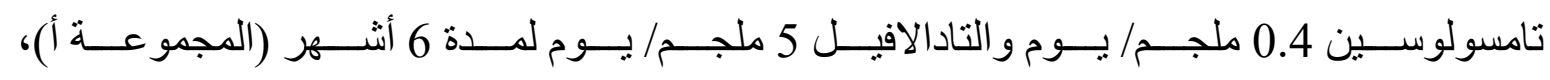

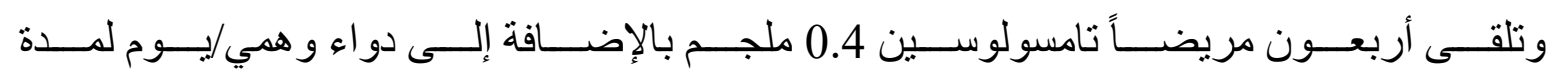

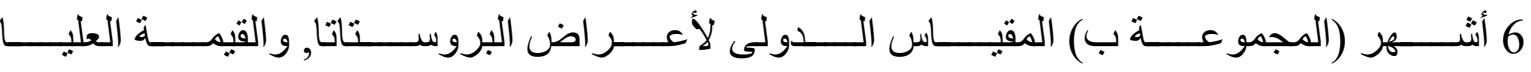

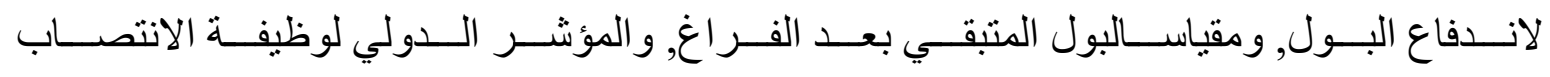




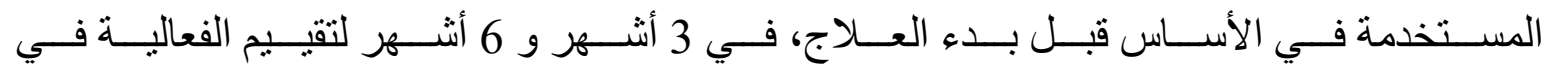

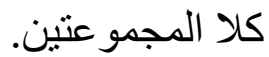

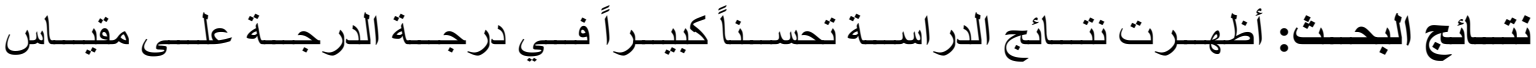

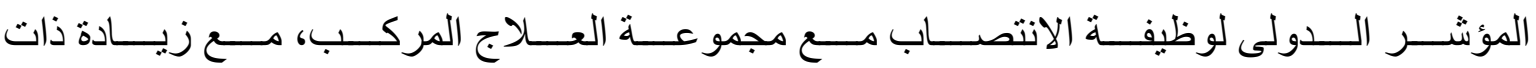

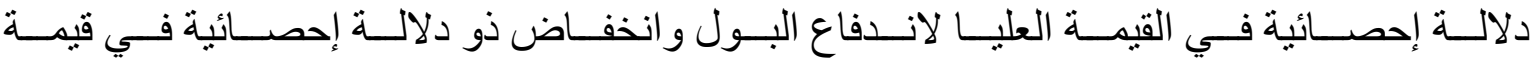

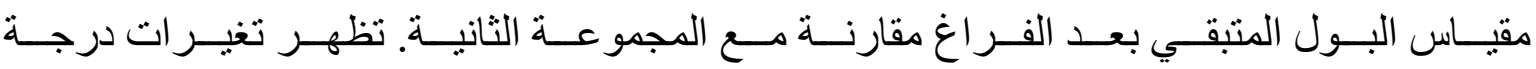

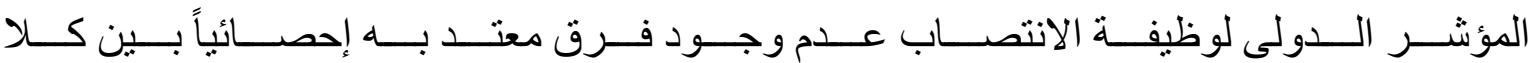
المجمو عتين قيمة 0,102في مجمو عة التادالافيل.

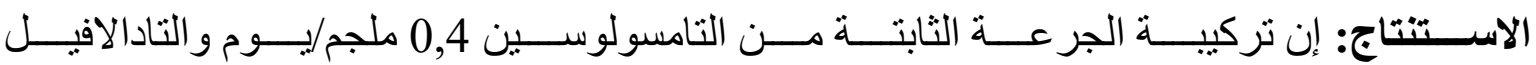

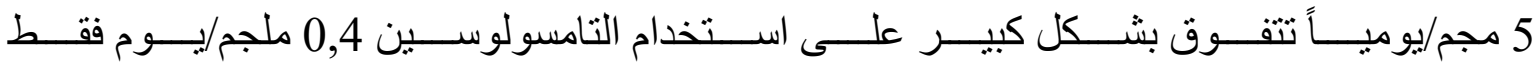

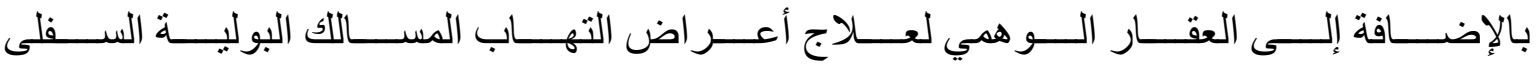

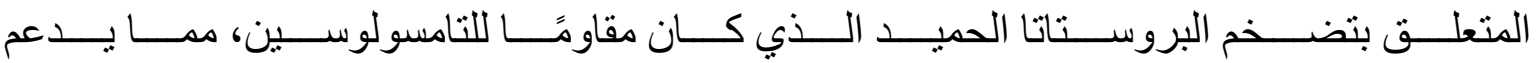

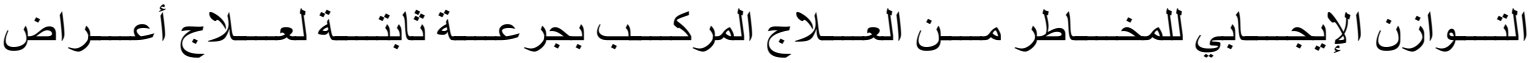

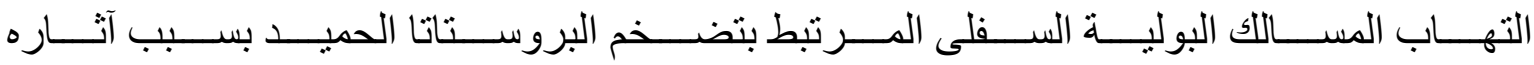

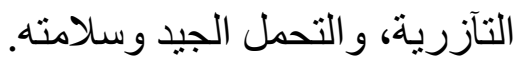

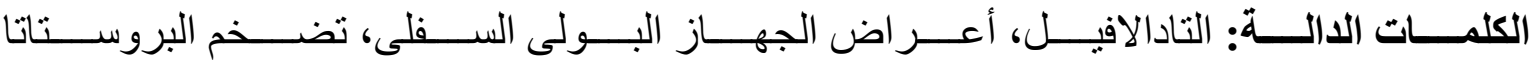

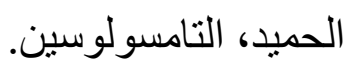

